\title{
Conservation Units and Sustainable Development Goals: An Examination of the Private Natural Heritage Dona Benta e Seu Caboclo in Brazil
}

\author{
Andreia Maria Roque ${ }^{1}$, Andressa Sales Coelho ${ }^{3}$, \& Claudia Moura de Melo ${ }^{1,2}$ \\ ${ }^{1}$ Tiradentes University (UNIT), Sergipe, Brazil \\ ${ }^{2}$ Institute of Technology and Research (ITP), Sergipe, Brazil \\ ${ }^{3}$ Federal University of Sergipe, Sergipe, Brazil \\ Correspondence: Andreia Maria Roque, Tiradentes University (UNIT), Sergipe, Brazil. E-mail: \\ andreia.roque@souunit.com.br
}

Received: August 16, 2021

doi:10.11114/ijsss.v9i6.5322

Accepted: September 17, $2021 \quad$ Available online: September 27, 2021

URL: https://doi.org/10.11114/ijsss.v9i6.5322

\begin{abstract}
The 2030 Agenda is a global action plan presented by the United Nations (UN) that establishes Sustainable Development Goals (SDGs. Conservation Units (UC) are an important element of the strategy towards nature conservation. Starting from a local approach to critically analyze these issues of global relevance, the focus of the investigation is the Dona Benta e Seu Caboclo Natural Heritage, a private conservation unit located in the municipality of Pirambu in the state of Sergipe and the community surrounding the Lagoa Redonda settlement. The study aimed to analyze the perception of the owner and the community regarding the environment, RPPN, and SDGs in order to build a critical approach to the issues that interconnect nature conservation and sustainable development. The methodology is based on the interview with the owner and a focus group with the community, carried out between January and March 2020. Following these interviews, it was ascertained that there is a divergence in how public and private lands are understood by locals: Private lands are exclusively associated with production, whilst public land is associated with conservation. Community representatives do not recognize RPPN as a conservation area, with those associated objectives. Yet, debates on the environment and sustainable development intertwined with nature conservation are recognized by everyone as a priority. In the end, it is possible to recognize the importance of strengthening a space for coexistence between the local population and the RPPN in order to implement common and transformative actions in favor of conservation, and sustainable development.
\end{abstract}

Keywords: conservation units, sustainable development goals, territories environment

\section{Introduction}

In 2015 the United Nations (UN) presented the 2030 Agenda and the Sustainable Development Goals (SDGs) as a global action plan that proposes to support governments in designing public policies for development; combining economic, social and environmental concerns. The 2030 Agenda is composed of 17 SDGs, interconnected among themselves, understood through the lens of five principles: people, prosperity, peace, partnerships, and the planet promoting environmental management integrating natural resources and ecosystems (Unite Nations, 2015).

The set of SDGs established to guide actions in favor of maintaining the natural resources and ecosystems of Agenda 2030 are focused on achieving water security on the planet, adopting clean and accessible energy, sustainable conservation of the oceans, seas, and marine resources, as well as protecting terrestrial ecosystems and combating global climate change. Since the adoption of the 2030 Agenda, it is possible to recognize efforts by environmental governance in order to bring the local realities closer to the goals proposed by the SDGs that guide actions for the integrated and sustainable management of natural resources and ecosystem. These efforts also to go through the local realities of the Conservation Units.

UCs are territorial spaces for environmental protection; they possess relevant natural characteristics and are recognized as effective instruments for the preservation and conservation of nature (Newsome and Hughes, 2018). UCS are territorial spaces that support biodiversity conservation and socioeconomic development (Bhammar el al., 2021). 
In Brazil, they were legally instituted and regulated in 2000 by the SNUC - National System of Conservation Units. The SNUC not only unified the legal treatment of the units but also characterized them according to their management objectives and types of use for the purpose of nature conservation (Brasil, 2000).

Recognizing the importance of reflection on how these themes interact with each other, this article integrates broader research developed in the Health and Environment Program (PSA) of the University Tiradentes (UNIT) entitled "Sustainable Development Goals (ODS) and Private Reserves of Heritage Natural (RPPN) in Brazil, proposing beginning from a local approach of the Private Reserve of Natural Heritage (RPPN) Dona Benta and Seu Caboclo, and the surrounding community in Povoado Lagoa Redonda, in order to critically analyze this is a global reality.

\section{Tracing the Path of the 2030 Agenda}

The United Nations (UN) in 1972 promoted the Conference on the Human Environment, also known as the Stockholm Conference, with the objective of debating themes related to the importance of the preservation of nature and the role of society in doing so.

The Stockholm Conference was the first major global conference focused on environmental degradation and policies of human development. The United Nations for the Environment (UNEP) was created from this conference, and has since been working on issues related to the environment in conjunction with governments and other organizations (Seyfang, 2003).

According to Corea do Lago (2007) one of the great merits of the Stockholm Conference was to bring to the world agenda discussions such as the repercussion of pollution on people's quality of life, previously only privately debated by national diplomats. Thus, it is necessary to recognize that other major environmental issues, such as sustainable development or the difficulties in implementing the recommendations focused on environmental preservation are only debated today, driven by the global meetings that have taken place since then.

In 1992, twenty years after the Stockholm Conference, Rio de Janeiro hosted the United Nations Conference on Environment and Development (UNCED), also known as Eco-92 or Earth Summit. The Earth Summit not only produced important documents, such as the Rio Declaration on Environment and Development and the Declaration of Principles on the Use of Forests, bringing debates on development, environmental protection, and social justice to the world agenda but also culminated in the approval of "Agenda 21"(Kumar,2020).

According to Malheiros et al. (2007), Agenda 21 not only proposed to the signatory countries of the UN a new model of sustainable development, but also, put pressure on States to develop strategies and plans adapted to local realities in favor of sustainable development.

In the year 2000, in the 55th. Session of the UN General Assembly in New York, with the presence of Heads of State and Government 191 nations, considering the themes previously proposed in Agenda 21, signed a commitment approving the "Millennium Declaration", a common document synthesized in eight Millennium Development Goals (MDGs), with the objective of enshrining into governmental strategies the goal of combatting problems such as extreme poverty, gender equality and environmental sustainability (Unite Nations, 2000).

Continuing this series of world meetings on the environment proposed by the UN in 2002, the World Summit on Sustainable Development, also known as Rio +10 , was held in Johannesburg, South Africa. And in 2012, the debates returned to Rio de Janeiro at the United Nations Conferences on Sustainable Development also known as Rio +20 , when the document entitled "The Future We Want" was presented, proposing new challenges to the signatory governments, addressing topics such as the green economy and sustainable development (Unite Nations, 2012).

During Rio + 20, the "General Assembly Open Working Group on Sustainable Development Goals" was created, and is made up of representatives of governments and social, technical, and civil society organizations with the purpose of preparing a new document that could synthesize the new set of actions and priority goals aimed at a new world development agenda (Unite Nations, 2014).

In 2015, representatives of the 193 UN member states meeting at the General Assembly in New York approved this new document now entitled "Transforming Our World: The 2030 Agenda for Sustainable Development" composed of 17 Sustainable Development Goals (SDGs) and 169 goals that brought to the agenda topics such as; Eradication of poverty; Sustainable agriculture and zero hunger; Health and wellness; Quality education; Gender equality; Sanitation and drinking water for all; Clean and affordable energy; Decent work and economic growth; Industry innovation and infrastructure; Reduction of inequalities; Sustainable city and communities; Responsible consumption and production; Action against global climate change: Life on the water; Earth life; Peace, justice and effective institutions and finally the importance of institutional partnerships and means of implementation (Unite Nations, 2015). 


\section{Conservation Unit (UC): Private Natural Protection Reserve}

Conservation Units (UCs) are natural areas recognized as effective instruments for the preservation and conservation of nature (Correa,2021; Gatti 2017; Brasil,2006)

In Brazil, UCs were instituted from the enactment of Law No. 9.985 / 2000 when the National System of Conservation Units (SNUC) was created, which unified the legal treatment of the units and characterized them into two large groups according to their objectives of management and types of use. The Integra Protection UCs, those where the indirect use of their natural attributes is allowed, and the UCs for sustainable use, where it is possible to make nature conservation compatible with the use of part of their natural resources. Created at the Federal, State or Municipal level, they are subdivided into the categories: Ecological Station; Biological Reserve; National park; Natural Monument; Wildlife Refuge; Environmental Protection area; Area of Relevant Ecological Interest; National Forest; Extractive reserve; Wildlife Reserve; Sustainable Development Reserve; Private Reserve of Natural Heritage (Brasil,2000).

RPPNs are units constituted in an area of possession and private domain by the voluntary act of the rural owner who publicly undertakes to conserve nature and to use it exclusively for the development of scientific research, visitation for tourism, recreational purposes, and educational activities (MMA, 2011).

According to the panel of Indicators of the National Confederation of RPPNs (CNRPPN), there are a total of 1663 RPPNs totaling 806,498.86 ha of preserved area. In total, 684 of the RPPNSs are located in the Southeast Region (41.13\%), 416 in the South Region (25.01\%), 344 in the Northeast Region (20.69\%), 165 in the Midwest Region (9.92\%), and 54 in the Northern Region of Brazil (3.25\%) (CNRPPN, 2020).

The RPPN Dona Benta and Seu Caboclo, the area of this study, was created through the ICMBio Ordinance No. 71 of August 27, 2010 as an environmental protection instrument for the Atlantic Forest biome (ICMBio, 2016).

Part of the Fazenda Cordeiro de Jesus rural property, which has a total territorial area of 97 ha, this RPPN is located in the Hydrographic Basin of the Japaratuba River in the Municipality of Pirambu, North Coast of the State, see figure 1.

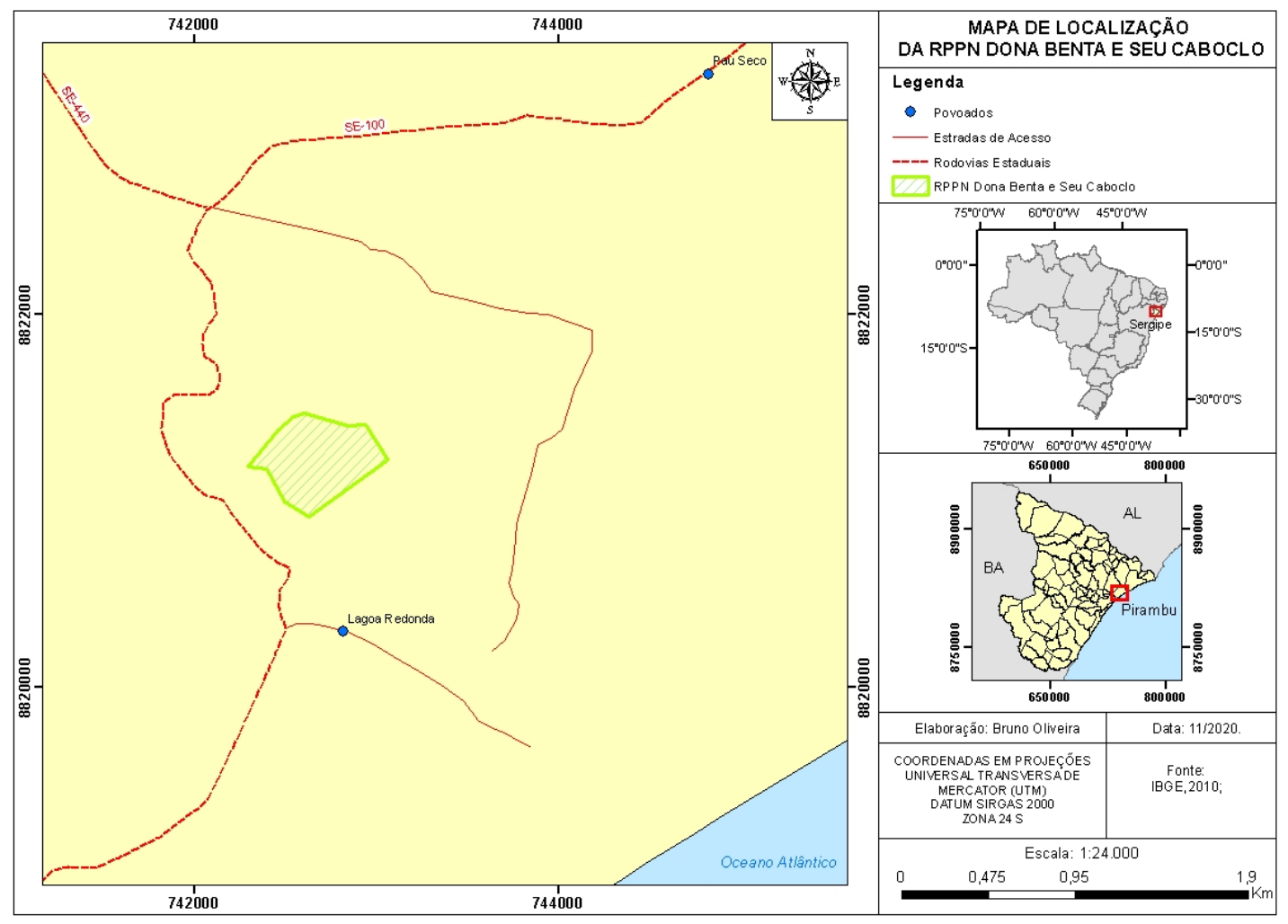

Figure 1. Location Dona Benta and Seu Caboclo Reserve. Source: IBGE (2010) 


\section{Methodological Procedures}

In this study, the Case Study research technique was adopted with the owner of the RPPN and the Focal Group with members of the Povoado Rural Lagoa Redonda community. The research project upon which this article is based was submitted and approved by the UNIT Research Ethics Committee in November 2019 with CAAE 0047519.5.000.5371.

The criteria established for choosing RPPN Dona Benta and Seu Caboclo were as follows: Being an RPPN located in the State of Sergipe, thus meeting the requirements of the research program in which it is linked, which establishes Sergipe as a priority territory for studies; Have your management plan approved; Be an open UC for scientific research and visitation for tourism, recreational and educational purposes. For data collection with the owner of the RPPN, a script of interviews was prepared, composed of clear and unambiguous questions, with the purpose of knowing the motivation for the creation of this RPPN and the activities allowed in the area. As well as understanding, from the perspective of the RPPNista, the relations between the universe of the RPPN and ODS and which public policies would be fundamental for the strengthening of the RPPNs in Brazil and specifically in Sergipe. The interview was conducted in January 2020, and the data collected were treated through Discourse Analysis (AD), which according to Gatti (2005), allows interpreting and recognizing language not only as a linguistic form, but also, as a repository for understanding the social values and cultural narratives by which its speakers live.

In a second moment to collect the data with the community of Povoado Lagoa Redonda, the research technique Focal Group was adopted, which according to Gatti (2005, p.11), allows us to

"... understand everyday practices, actions, and reactions to facts and events, behaviors and attitudes, building an important technique for the knowledge of representations, perceptions, beliefs, habits, values, restrictions, prejudices, languages and symbols."

The interview was conducted in January 2020, and the data collected were treated through Discourse Analysis (AD), which according to Careganato (2006), allows interpreting and recognizing language not only as a linguistic form, but also, as a repository for understanding the social values and cultural narratives by which its speakers live.

In a second moment to collect the data with the community of Povoado Lagoa Redonda. The discussion process with members of the community took place in March 2020 in a collective area of the village, lasted for four continuous hours, and was attended by ten residents of the community. In this study, the criteria adopted for choosing participants in the focus group were: Being over 18; Interested in the proposed themes; Be willing to participate in discussion with other members of the community.

For the treatment of the data, Content Analysis (CA) was carried out, which according to Bardin (1977), is "a set of techniques of analysis of communications aiming to obtain by systematic procedures the description of the content of the messages."

Using the Iramutec software (Interface of R pour les Multidimensionnelles Analyzes de Textes et de Questionnaires), allows different forms of analysis, among them the similarity analyzes adopted in this study for the grouping and organization of words graphically (Loubère and Ratinaud 2014).

\section{Results and Discusión}

Historically, the entire northern coastal strip of the State of Sergipe suffers from the depredation of natural resources and almost total extinction of the Atlantic Forest. The conflicts that permeate this coastal ecosystem constitute a series of socio-environmental impacts that point to losses of natural and cultural resources. From the perspective of territorial planning, the North Coast of Sergipe is perhaps the most conserved area in the state, thanks to its preserved natural areas that house three of the state UCs. One of them being the Santa Isabel Biological Reserve (REBIO), an important federal area of integral protection established in 1988, in addition to the RPPN Morro da Lucrécia and the RPPN Dona Benta and Seu Caboclo, constituted respectively in 2012 and 2010 (Barreto, 2019). It is in this context that the Cordeiro de Jesus Farm, which houses the RPPN Dona Benta and Seu Caboclo, known as the "Lagoa do Avô" Farm, formerly focused on coconut production, and after being acquired by the current owner, changed its name, created RPPN and became the headquarters of the nature preservation, leisure, and tourism complex Ecomuseo do Roceiro. According to the interviewed interviewer, there are many motivations that a rural landowner has to create an RPPN, but what motivated him personally was his ideal of keeping the local ecosystem intact from the stimuli of local technicians from environment agencies.

"...So, I can say that respect for nature in my case comes from birth. But I wanted to go beyond respect, I wanted to have a farm, produce organics, preserve the forests and animals until the opportunity arose to acquire a property with all the natural elements I was looking for (water, forest, animals, dunes, communities, etc.) to start my project." 
" ...But I wanted to go beyond respect, I wanted to have a farm, produce organics, preserve the bush and animals until the opportunity arose to acquire a property with all the natural elements I was looking for."

Reflecting on the role of RPPN Dona Benta and Seu Caboclo as a propelling tool for the sustainable development of the territory, the search for partners with educational institutions and the like, relationship with the community, and ecotourism programs are the guiding axes of the unit according to reports by the RPPN manager .

"In the Research and Monitoring Program, several researches have already been carried out, covering fauna, flora, tourism and the communities surrounding the RPPN, through educational institutions: UFS, IFS, UNIT, Faculdade Jardins, UFPE, UFRJ and Schools of the County."

About the perception of the owner of the RPPN about the 2030 Agenda and the SDGs Reaffirming the integration of all objectives with each other and emphasizing that the 2030 Agenda is a tool for bringing the community closer together, as it encourages interaction with nature in a more harmonious and sustainable way, see Table 1.

Table 1. Interpolation between the realities experienced in the RPPN Dona Benta and the SDGs of the 2030 Agenda according to the RPPNista

\begin{tabular}{|c|c|}
\hline Sustainable Development Goals & RPPN Experiences Dona Benta and Seu Caboclo \\
\hline SDG 03 Health and Wellness & $\begin{array}{l}\text { The RPPN directly preserves the local faunal flora. } \\
\text { The RPPN preserves the springs }\end{array}$ \\
\hline SDG 04 Quality Education & $\begin{array}{l}\text { The RPPN provides a more harmonious and sustainable interaction } \\
\text { between man and nature. } \\
\text { RPPN makes it possible for students from schools in the communities } \\
\text { to visit in order to experience their environment from another angle (environmental } \\
\text { education activities linked to formal education). } \\
\text { Quality education must also consider ways of improving the local } \\
\text { environment. }\end{array}$ \\
\hline $\begin{array}{l}\text { SDG } 11 \text { Sustainable Cities and } \\
\text { Communities }\end{array}$ & $\begin{array}{l}\text { RPPN allows direct contact with natural assets. } \\
\text { RPPNs preservation model causing minimal impact on the environment with } \\
\text { environmental education campaigns for surrounding communities and visitors. }\end{array}$ \\
\hline SDG 13 Action Against Climate Change & $\begin{array}{l}\text { Spring preservation action. } \\
\text { Action against deforestation in the surrounding areas. } \\
\text { Appreciation of local attitudes that have a positive impact on actions against climate } \\
\text { change. }\end{array}$ \\
\hline SDG 15 Life on Earth & $\begin{array}{l}\text { RPPN "Preserves Life on Earth" / Without preserved areas, monoculture of sugarcane / } \\
\text { coconut grows. } \\
\text { Without preserved areas there is no mangaba tree. With it there is no longer a set of } \\
\text { beings that were very important for the environment. }\end{array}$ \\
\hline $\begin{array}{l}\text { SDG } 17 \text { Partnerships and Means of } \\
\text { Implementation }\end{array}$ & $\begin{array}{l}\text { Cooperation with formal teaching and research institutions (UFS, IFS, UNIT, UFRPE } \\
\text { and Faculdade Jardins). }\end{array}$ \\
\hline
\end{tabular}

Source: Prepared by the authors (2020)

A Look Beyond the Gate: Focus Group Populated Lagoa Redonda. The Lagoa Redonda Village, located on the North Coast of Sergipe in the area surrounding REBIO Santa Isabel and the RPPNs Dona Benta and Seu Caboclo, has its population measured by IBGE (2010), the approximately 350 residents make their income from extraction followed by fishing activities, subsistence agriculture and tourism (Sergipe,2020). According Braghini \& Vilaret (2013), since the creation of REBIO Santa Isabel, discontent arose in the region by the population of the village, because at the same time that this unit brought national prominence to the locality, it also established restrictive norms of access to resources existing in that territory. Regarding the perception of local communities about the RPPNs. It is observed in the similarity analysis graph that a significant number of participants do not know about the existence of the RPPN nor its objectives, but they know the rural property Cordeiro de Jesus farm where the RPPN Dona Benta and Seu Caboclo is located as well as the owner, see Table 2 . 
Table 2. Similitude Analysis: Answers to the guiding question "Do you know the RPPN Dona Benta and Seu Caboclo and know that it is a Private Natural Heritage?"

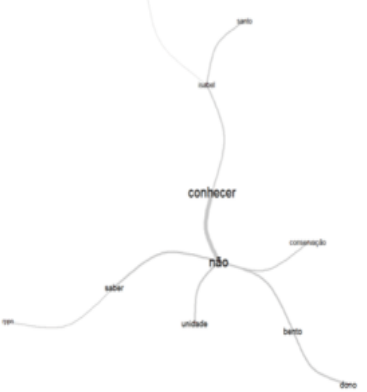

1. It is observed that there are words that stand out most in the discourse. Reaffirming occurrences between words indicating convexity between them.

2. It is observed that the words that stand out most in the speeches reaffirm the local narrative of ignorance of the RPPN as a preservation area.

3. From the prominent word, other words that have a significant expression are branched out, reaffirming the narrative of knowing REBIO Santa Isabel as a conservation unit.

4. At the end of the ramifications, there is the relationship between private rural property with an "owner" and not as a conservation unit.

Source: Prepared by the authors (2020)

The possibility of having a natural preservation area on private land was a topic that caused strangeness and aroused the curiosity of the participants who refer to conservation units as public areas, alluding to REBIO Santa Isabel as being "that government area closed to the population."

Linked to the local understanding that conservation areas only exist on public lands and that private lands are associated exclusively with production, community representatives do not recognize the RPPN as a nature conservation area, and neither its objectives, they do however identify that being a preservation area, with tourism potential, could generate more jobs for the local population. Regarding environmental issues, there is a local narrative valuing the importance of debates on the theme, however, such statements are related exclusively to nature preservation. They reaffirm the importance of debates on the environment and highlight the importance of the participation of children in the community in these debates. But they also demonstrate a careful look for survival, bringing in the discourse not only the values focused on the need to preserve the place where they live but also the village's potential for tourism and the promotion of sustainable agriculture and fishing by proposing partnerships with RPPN Dona Benta and Seu Caboclo focusing on tourism development actions, see Table 3 .

Table 3. Similitude Analysis: Answers to the guiding question "Do you know the RPPN Dona Benta e Seu Caboclo and know that it is a Private Natural Heritage?"

1.It is observed that there are words that stand out in the
speech reaffirming the occurrences between the words and
the indications of the convexity between them. It is observed
that there are words that stand out most in the speeches
reaffirming the local narrative of the importance on the
environment, but directly related to the values intrinsic to
nature.
2.From the prominent word, other words branch out that
present a significant expression of the future narrative
interconnected with the role of children in the community.
3. At the end of the ramifications, the relationship between
nature and the future is contemplated.

Source: Prepared by the authors (2020)

In the presentation of the guiding questions in the focus group on the 2030 Agenda and SDGs. Although, according to the UN, the document "Transforming Our World: The 2030 Agenda for Sustainable Development", composed of 17 Sustainable Development Goals (SDGs) integrated among themselves, establishes that the involvement of different segments of the population is as important as the participation of companies and governments.

The distance between the population and the 2030 Agenda, and its proposed objectives, is clear when the theme arouses the curiosity of the participants, and almost all respondents stated that they do not know the SDGs or their purposes.

It is observed that there is a single negative word that stands out in the speech reaffirming the few occurrences between the words and the indications of convexity. It is also observed that there is no discourse formed about the SDGs, see Table 4. 
Table 4. Similitude analysis of the answers to the guiding question "Do you know what the Sustainable Development Goals (SDGs) are? Do you know what the purpose is?

It is observed that there is a single word that stands out in the speech reaffirming the few occurrences between the words and the indications of convexity.

It is observed that the refusal to the theme reaffirms the local narrative of ignorance of the SDG.

The prominent word does not branch out with other words.

There is neither extreme nor ramifications showing little contact or knowledge with the SDG theme

Source: Prepared by the authors (2020)

Which allowed the participants of the focus group to correlate some realities experienced in the village with the objectives set out in the 2030 Agenda, see Table 5

Table 5. Interpolation between the realities experienced in Povoado Lagoa Redonda and the SDGs of Agenda 2030 according to focus group participants

\begin{tabular}{|c|c|}
\hline SDG & Reality Experienced Village Lagoa Redonda \\
\hline SDG 01 Poverty Eradication & $\begin{array}{l}\text { More job opportunities. } \\
\text { We invest more in the generation of opportunities }\end{array}$ \\
\hline SDG02 Hunger and Sustainable Agriculture & $\begin{array}{l}\text { Best agricultural practices } \\
\text { Greater interest from young people } \\
\text { Greater knowledge of native flora } \\
\text { Ensuring a right to quality food }\end{array}$ \\
\hline SDG 03 Health and Wellness & $\begin{array}{l}\text { Improve road infrastructure to reduce accidents } \\
\text { Improve security } \\
\text { Medication access }\end{array}$ \\
\hline SDG 04 Quality Education & $\begin{array}{l}\text { School for young people to stay in the community } \\
\text { Technical schools for youth and adults } \\
\text { Tourism and gastronomy courses } \\
\text { Environmental monitors courses } \\
\text { More environmental education practices }\end{array}$ \\
\hline SDG 07 Accessible Energy & $\begin{array}{l}\text { Cheaper energy } \\
\text { Less taxes } \\
\text { Greater access to other energy sources, such as solar }\end{array}$ \\
\hline SDG 8 Descending Work Economic Growth & $\begin{array}{l}\text { Best opportunities / More activities to keep young people in the } \\
\text { community } \\
\text { Encourage creativity and new opportunities } \\
\text { Youth and women work }\end{array}$ \\
\hline SDG13 Action Against Change Global Climate & $\begin{array}{l}\text { Greater awareness of everyone in the community / partners and } \\
\text { tourists More development policies but taking care of the } \\
\text { environment and climate change }\end{array}$ \\
\hline SDG 15 Life on Earth & $\begin{array}{l}\text { Improving the community's quality of life } \\
\text { Incentives for good environmental practices } \\
\text { Preserve and think about improving living conditions }\end{array}$ \\
\hline SDG 17 Partnerships and Implementation Means & $\begin{array}{l}\text { Partner with RPPN and Pr } \\
\text { Involvement with UC Santa Isabel's decisions } \\
\text { Partnerships with Colleges and City Hall }\end{array}$ \\
\hline
\end{tabular}

Source: Prepared by the authors (2020) 


\section{Conclusion}

Starting from a local approach to critically analyze a topic of global relevance was a challenging proposal, albeit one that allowed a critical approach towards the issues that interconnect nature conservation and local, sustainable development.

It is believed that one of the contributions of this article is, in addition to reflecting how themes such as the SDGs and UCs interconnect with each other in Brazil, bringing more critical and reflective participation from the community. Reconciling the protection of natural resources associated with practices that enable sustainable development to be achieved, prosperity and appreciation of people are increasingly required and demanded by local society.

It is observed that RPPN Dona Benta e Seu Caboclo consists of a UC category with ample conditions to assist in this dialogue, because it has as a main characteristic, the owner voluntarily adheres to rules designed for the conservation of nature, but also using the area for tourism, leisure and environmental education. However, the local understanding that conservation units exist only on public lands while private lands are associated exclusively with the extraction and use of raw materials, and not as a preservation place compels us to reflect on the need to strengthen an integration space and coexistence between the local population and the RPPN in order to establish these links between the actors.

The importance of analyzing the perception of the surrounding community about the RPPN is focused upon in order to know the meanings and attitudes that govern such local relations. Alongside this, as a means of examining the possibility of adopting the SDGs script proposed by Agenda 2030 as a tool for recognizing the local reality so that it can support municipal and state governments in the design of public policies and partnerships between local agents. There are also some final reflections on why environmental debates are important in rural communities close to preservation areas and how these paths can be built, recognizing in dialogue and environmental education paths that can facilitate and strengthen the space of coexistence between community universes; between rural productive and natural preservation areas.

\section{Acknowledgements}

Tiradentes University (Unit), Institute of Technology and Research and the Coordination for the Improvement of Higher Education Personnel Brazil (CAPES). This work was supported by the Coordination for the Improvement of Higher Education Personnel - Brazil (CAPES) - Financing Code 001.

\section{References}

Bardin, L. (2011). El Análisis de Contenido (3rd ed.). Madri: Publishing Company AKAL.

Braghini, C. R., \& Vilar, J. W. C. (2013). Gestão territorial de áreas protegidas no litoral: primeiras incursões. Revista Ambivalências, 1, 1-14. https://doi.org/10.21665/2318-3888.v1n1p115-128

Brammar, H., Li, W., Molina, C. M. M., Hickey, V., Pendry, J., \& Narain, U. (2021). Framework for Sustainable Recovery of Tourism in Protected Areas. Sustainability, 13(5), 2798. https://doi.org/10.3390/su13052798

Brasil. (2000). Lei Federal $n^{\circ}$ 9.985, de 18 de julho de 2000 - Dispõe sobre o Sistema Nacional de Unidades de Conservação da Natureza-SNUC. Brasília: DOU de 19/07/2000.

Brasil. (2006). Decreto $n^{\circ} 5.746$, de 5 de abril de 2006. Regulamenta o art. 21 da Lei $n^{\circ}$ 9.985, de 18 de julho de 2000. Dispõe sobre o Sistema Nacional de Unidades de Conservação da Natureza em 2006. Brasília: DOU de 06/04/2006.

Careganato, R. C. A., \& Mutti, R. (2006). Qualitative research: discourse analysis versus content analysis. Revista Texto Contexto Enfermagem, 15(4), 679-684. https://doi.org/10.1590/S0104-07072006000400017

CNRPPN - National Confederation of Private Natural Heritage Reserves (2000). Indicators Panel. 2020. Retrieved from https://datastudio.google.com/u/0/reporting/0B_Gpf05aV2RrNHRvR3kwX2ppSUE/page/J7k

Correa do Lago, A. A. (2007). Estocolmo, Rio, Joanesburgo: o Brasil e as Três Conferências Ambientais das Nações Unidades. Brasília: Fundação Alexandre Gusmão.

Corrêa T. C. V., Mendes, L. M. de Melo, Barbosa, K. J. V., \& Melo, F. R. (2021). Medium and large-sized mammals in Private Natural Heritage Reserves in the Quadrilátero Ferrífero of Minas Gerais, Brazil. Neotropical Biology and Conservation, 16(2), 383-396. https://doi.org/10.3897/neotropical.16.e62189

Gatti, A., Ferreira, P. M., Cunha, C. J. da, Seibert, J. B., \& Moreira, D. de O (2017). Medium and Large-Bodied Mammals of The Private Reserve of Natural Heritage Recanto das Antas, In Espirito Santo Brasil. Oecologia Australis, 21(2),171-181. https://doi.org/10.4257/oeco.2017.2102.07

Gatti, B. A. (2005). Grupo focal na pesquisa em ciências sociais e humanas (1st ed.). Brasília: Publishing company. IBGE - Instituto Brasileiro de Geogragia e Estatitistica. (2010). Censo Demográfico. Retrieved from www.ibge.gov.br 
ICMBio - Chico Mendes Institute for Biodiversity Conservation. (2016). Management Plan for the RPPN Dona Benta e Seu Caboclo. Retrieved from http://www.icmbio.gov.br/portal/images/stories/DCOM_plano_de_manejp_RPPN_-Dona_Benta_e_seu_Caboclo.p df.2016

Kumar, R. (2020). The United Nations and Global Environmental Governance, Strategic Analysis, 44(5), 479-489. https://doi.org/10.1080/09700161.2020.1824462

Loubère, L., \& Ratinaud, P. (2014). Documentation IraMuTeQ 0.6 alpha 3 - version 0.1 [Computer software]. Retrieved from http://iramuteq.org/documentation/fichiers/documentation_19_02_2014.pdf

Malheiros, T. F., Philippi Jr, A., \& Coutinho, S. M. (2007). Agenda 21 e indicadores de desenvolvimento sustentável: contexto brasileiro. Saúde e Sociedade, 17(1), 7-20. https://doi.org/ 10.1590/S0104-12902008000100002

MMA - Ministry of the Environment. (2011). SNUC: National System of Nature Conservation Units Law $n^{\circ} 9.98518$ de July de 2000; Decree $n^{\circ} 4.340$, de 22 de August de 2002; Decree $n^{\circ}$ 5.746, de 5 de April de 2006. National Strategic Plan for Protected Areas: Decreto $n^{\circ}$ 5.758, de 13 de abril de 2006.Brasilia: MMA.

Newsome, D., \& Hughes, M. (2018). The contemporary conservation reserve visitor phenomenon! Biodiversity and Conservaction., 27, 521-529. https://doi.org/10.1007/s10531-017-1435-4

Sergipe Estado/ SEGG Secretaria de Estado Geral de Governo. (2020). Banco de Indicadores. Retrieved from https://www.observatorio.se.gov.br/app/anuarioestatistico?categoria=demografia

Seyfang, G. (2003). Environmental mega-conferences-from Stockholm to Johannesburg and beyond. Global Environmental Change, 13, 223-228. https://doi.org/10.1016/S0959-3780(03)00006-2

Silva, E. R. C. de. (2018). Os Objetivos do Desenvolvimento Sustentável e os desafios da Nação. Brasília In IPEA (Eds.) Desafio da Nação: Artigo de Apoio Brasília (659-678). Negri, J. A; Araújo, B. C.; Bacellette, R.

United Nations. (1992). Earth Summit: Agenda 21 The United Nations Program of Actions. Retrieved from https://sustainabledevlopment.un.org/content/documents/Agenda21.pdf

United Nations. (2000). United Nations Millennium Declaration 2000. Retrieved from https://sustainabledevelopment.un.org/content/documents/733FutureWeWant.pdf

United Nations. (2015). Transforming Our World: the 2030 Agenda for Sustainable Development. http://sustainabledevelopment.un.org/content/documents/21252030\%20Agenda\%20for\%20Sustainable\%20Develo pment

\section{Copyrights}

Copyright for this article is retained by the author(s), with first publication rights granted to the journal.

This is an open-access article distributed under the terms and conditions of the Creative Commons Attribution license which permits unrestricted use, distribution, and reproduction in any medium, provided the original work is properly cited. 